\title{
Education, Power, and Personal Biography: An Interview with Michael Apple ${ }^{1}$
}

\author{
Raymond A. Morrow
}

\author{
Carlos Alberto Torres \\ University of Alberta
}

Morrow: One of our objectives today is to give a sense of the political culture of education in relation to American society and particularly to contextualize that a bit for Canadian students for we have a somewhat different situation. I think the key thing to understand is that Michael Apple is one of the leading representatives of a new current in educational scholarship in the United States which goes under many different names: radical, critical, and so forth, but I think one of the key distinctions is to see it in terms of its origins as a critique of American liberalism. So I think the first question I would like to address is the origins of your work in a critique of liberalism and the particular contradictions of American society in relation to education.

Apple: This has to be in part autobiographical, as you would imagine. I have an odd history. I did my undergraduate work at night while I was working as a union printer and truck driver for a number of years. I come from a family that would have been pleased to be called working class and we were very poor. Because of this, there was a question about whether there was any money for me to go on to higher education. Given the fact that money simply wasn't there, I supported myself. I went to two small state teachers' colleges at night while I was working in the print shop in the day until I had to go into the army. While I was not overjoyed about this, to say the least, I went in the army. It seemed wiser to do that than to go to jail at the time. The army made me a teacher. I taught compass reading and first aid. After being discharged, I had one year of college credits. Urban schools in New Jersey were facing a massive teacher shortage, especially in schools serving "minority" children. I had taught in the army and could say "icomo esta?" which unfortunately was all you needed to be able to say, it seemed, in Paterson, New Jersey to be put in front of the classroom. I began teaching at the age of 19 as what was called a "floater," a

Phenomenology + Pedagogy Volume 81990 
full-time substitute as you would call it. Every morning at 6:45 I was told what school I would be in. I was always assigned to schools that were populated by children who were of color, partly because I was very active in the African-American and Hispanic communities in Paterson. I was one of the founding members of the Paterson chapter of CORE (Congress of Racial Equality) and had already done a good deal of activity involving literacy work and desegregation in the south of the United States. The south had areas where they closed black schools rather than have black children and white children go to the same school. I and others would go down there on buses (some of which were burned) and many of us were jailed. I went down to reopen literacy classes for African-American children. Thus I was politicized at a time in which you had to act on it, politicized as an educator. I was someone who, even though I was not really trained as a teacher, was deeply involved in political, cultural, and educational struggles in the south in the U.S. Because of this, I was formed by racial conflicts over the politics of literacy, the politics of access, etc. This is important, I think, to understand why I move in certain directions. By situating what I do in these fairly young experiences in political engagements, it's possible to see why the politics and struggles in education have always formed me in significant ways.

Morrow: These events would have been in the early to mid '60s?

Apple: The late '50s, early '60s. I got out of the army in 1962.

Morrow: You were really on the ground floor of a whole series of very powerful movements and confrontations.

Apple: Yes, this was even before the "end the war" movement. While I was teaching in New Jersey, it became quite clear to me that the kinds of struggles I was engaged in in the south needed to be broadened. Much of this was because of Paterson itself. Paterson is the third worst-off city of its size in the United States. It now has a large portion of the population on some form of assistance and an $80 \%$ "minority" population with almost no right to a decent economic life. I say "minority" because people of color are the majority in the world, and the word minority is definitely an ideological construction.

Again it was politicization that led me to begin teaching in a particular way. I was quite angry about what I was seeing around me. The schools were largely failing. The knowledge was filtered through ideologically laden curricula. And the rich cultures of working-class and "minority" life and history were totally absent. Thus the politics of knowledge and the politics of teaching had to be transformed with my own actions in class- 
rooms. Having to put this stuff into practice every time you walked into the classroom meant that the reading and political work I was doing was translated immediately into what I had to do when I faced the 46 children in my classroom every day. I was still deeply involved in racial politics and class politics at the level of practice in Paterson and the educational practice inside schools and political practice in the larger community together continued to form me.

From there I got deeply involved in teacher politics. I was president of the teachers' union for a while. Again, I was disheartened by what I saw, and disheartened by the promises that were never kept_-all of which I think led me to certain readings as well as actions, especially to a critique of liberal policies. Paterson was a machine city. It was controlled as well by what in the United States was called a "Democratic administration," people who were of the mainstream Kennedy or Johnson liberal type who promised to wage a war on poverty. Yet no matter how much I and other people in education and political work would kill ourselves trying to make a difference in classrooms and elsewhere, all too many of the children still would wind up in jail, on drugs, with no jobs, in poverty, discriminated against, and often brutalized by the system.

Morrow: You were sitting on the front lines, while the bureaucrats are sitting in their plush offices thinking of solving the problems?

Apple: Yes, although in Paterson there weren't a heck of a lot of plush offices. But that is exactly the point. That led to a good deal of anger and partly to the search for my political roots. I am what is called a "red or pink diaper baby"-a joke which in the United States refers to someone with deeply involved leftist parents. This involved finding myself politically, not just as an activist in racial politics, but by situating myself in this long family tradition, which is more important. These autobiographical points are important for social theory as well, since critical theory often has its roots in senses of lived oppression as the feminist and antiracist movements have so clearly shown. From there I went on to graduate school at Columbia at a time when campuses in the United States were deeply polarized and politicized about the Vietnam War, racism, and so forth. This experience studying at Columbia enabled me to link my own educational and political history with an entire range of radical literature and to ground myself within it intellectually as well. 
Apple: Yes. And then moved from there to Wisconsin-a story that people may enjoy and that again may explain why I am in Madison as opposed to other institutions, especially given my politics and my penchant for not keeping an exclusive interest in writing, but in wanting to do something about it. When I was interviewed for a position here in Madison in 1970, there were literally tanks rolling down the streets in response to the strong antiwar movement on campus. This was a very liberal community in the best of that sense in those times. I knew when I was interviewed and during the interviews the building was tear gassed, well I knew that this was the place I wanted to be. So this is a personal story and also a political history. Finally, there are other things I think that contributed to my politicization. Speaking personally, I am the father of an Afro-American child. This means that not only again must $I$ work at the level of thinking these things through, but must live as someone who faces having the child come home from school every day angry, hurt, or scared because of racial polarizations, utter insensitivity on the part of the school, and so forth. This too increases my sense that I have to struggle every day. The phenomenology of children, and here my own children, adds something crucial.

Morrow: Let's shift to the specific content of your research strategy. In some of your retrospective reflections and introductions you've noted certain shifts in perspective, particularly the general movement from correspondence theory through a broader conception of the possibility of resistance. Could you briefly comment on how that has affected the direction of your work?

Apple: That makes it seem as if these shifts occurred primarily because of a shift in tradition of the theoretical literature. (We are going to have to think about this somewhat more dialectically I think.) Of course I was influenced by emerging debates within the various critical traditions, but political action causes different kinds of thinking. I tend to be fairly materialist about this-circumstances changed for me, and then things changed within me as well. Much of the work that I engaged in originally was something like politicized phenomenology. It tended to blend together some of the traditions of social phenomenology, Habermas, and critical theory (before these last two were changed into something safe). Furthermore, the person I had worked with at Columbia (Dwayne Huebner) also taught courses in liberation theology and phenomenology at Union Theological Seminary there. Much of the work that I engaged in originally was an attempt to blend together a nonstructuralist 
Marxist position with phenomenology because those were the two fields I was trying to pull together in some way. As these two traditions merged in my mind (and of course created tensions as well), part of the work that I began to engage in was an attempt to see how that merger could help us understand the politics of class in the actual curriculum, the way we think about class and education, and our own structural position as educators. Now what that meant was that I had to support the antiliberal positions of people like Bowles and Gintis in Schooling in Capitalist America-what has been called correspondence theory. For them, if you understand the hidden curriculum, you understand schooling, and the only way to understand it is to actually compare children by class trajectories. While I was a bit uncomfortable with this because of its unsubtle sense of culture, of the complexities of human experience, I wanted to support it because it seemed to me that it was at least an attempt at Marxifying a tradition and destablizing a more liberal tradition. On the other hand, I wanted to show and highlight the notion of culture as having some autonomy. The result was Ideology and Curriculum, a book, I trust, that helped to establish that culture has materiality, that it was influenced by but wasn't a total reflection of economic structure.

Morrow: So your kind of structuralism was motivated by incorporating culture as a theme whereby you actually became sensitized to it in the practical side of politics.

Apple: That's right.

Torres: In looking at the intellectual tradition of Marxism outside the U.S., there are two serious traditions that try in a way to fight against determinism and the authoritarianism of Stalinism: Althusserian structuralism and Gramsci's approach. The structuralist overtones are much more related to the French origins of Althusser than with the reading of Marxism. Althusser's is a particular reading of Gramsci. Whether one agrees or not with the reading is not the question here. The drawing board of Althusser is Gramsci. How would you escape drawing the same conclusions as Althusser did when you were reading Gramsci at that time?

Apple: I was taken by Althusser's structuralism, in part because of its emphasis on contradictory moments at a number of levels. It was not necessarily only the prison house for many people as it is made out to be. It was a reading of the Marxist tradition that enabled us to think about structure and the specificities of culture, and the specificities of the political. Of course, it is a prison in some ways, as any structural analysis can be; but it 
enabled us to think about the way culture was partly separate, and how it was relatively autonomous. After all, isn't this what a theory of contradictory levels is all about? So I was very taken with the Althusserian position, but clearly what it didn't do was allow any room for the point you made before, for human agency, for resistance, for struggle, since it was in fact ultimately guided by a logic of reproduction. The next books I wrote began to push at that. Education and Power began to look at the contradictory and not necessarily only reproductive relationship between culture, economy, and the state. It also began to look at gender and race as well as class dynamics. Ideology and Curriculum is an analysis by and large of domination and exploitation. It does end on a note of hope-about human agency, the next theme, but it was still primarily in class terms.

After I had written Ideology and Curriculum and Education and Power, I began to talk about some of the material on deskilling teachers and changes in the class position of teachers that are embodied in them. (Remember, I had been a president of the teachers' union, and had worked very closely with teachers and cinematographers on film work with children and teachers-beautiful, loving material with no overt political overtones, but which showed the very possibility of different ways of creating personal and political meaning in schools.) This meant I had a good deal of credibility with teachers. I was speaking with a group very similar to the Boston Women Teacher's Group in the United States, to part of the "feminist teachers' alliance" in Madison, and I was laying out the tradition of interpreting teachers' labor that I was attempting to build, and what that means in terms of their deskilling and loss of curricular control. After listening intently to me for quite a while, one teacher said, "Michael, did it ever dawn on you that you are speaking to 30 people who are sexed in particular ways?" And it was like a light bulb going off. It became crystal clear that class analysis itself, even with the focus on resistance and struggle that I had integrated into it, simply could not deal with the major fact that gender was the absent presence in most of our work. It was all too silent on the issue that teaching was an extension by and large of women's unpaid labor in the home. We cannot understand class without understanding gender. I was helped immensely here as well by my wife Rima, who is an historian of medicine whose focus is on the struggles by women to control their bodies and knowledge.

I began to move from a focus on the intricacies of class relations and nonreproductive forms to the immensely contradictory formations in education and elsewhere of class, race, and gender 
relations in politics, in economics, and in culture. That required a radical reconstruction of Althusserian theory. It included a theory of human agency and just as importantly included a theory of overdetermination, where class both helps produce gender and contradicts it, and both produce and contradict race. These are the dynamics that make up a social formation. They work their way out in the relatively autonomous spheres of culture, economy, and politics. This is an admittedly complicated theory. I've tried to lay it out clearly in the introductory chapter of Ideology and Practice in Schooling.

Morrow: That's much closer to the original Gramsci without the Althusserian epistemology. In many ways your work was not merely reflecting the changes in the literature and the radical education position, so much as reconnecting elements in your own biography and work in developing a more synthetic position.

Torres: That's right. In a way theory seems to be illuminating practice, which is a principle of a materialist perspective in culture. It is intriguing that a crucial aspect of your writings has not been reading, but interacting with people and being able to listen and be challenged.

Morrow: By this time the theory had gotten ahead of your practice, whereas before your practice was ahead of your theory?

Apple: Partly, but again an example is Education and Power which I think is actually a much more fluid book than the more structuralist reproductive readings in Ideology and Curriculum. Two political and personal, as well as scholarly, reasons account for this. As I just mentioned I began to work with a dissident women's group; yet I also began to work with a union group struggling to democratize in a Chevrolet plant in Wisconsin. One of my students was a Vietnam veteran and a political activist. I'd been to rallies with him and we had done some political work together. He couldn't get a job as a teacher and worked on an assembly line in a Chevrolet plant. He was trying to work with others to form a dissident union group that would challenge the union ideologies and structures that were quite conservative in the plant. They asked me to come and to help them build material for political education. This is part of my training-I was originally educated at Columbia in the curriculum area. My training as a curriculum worker meant that I could offer some assistance in how you create material that was responsive and, I hoped, powerful. As I began to work with this group, it was quite clear that the stuff I was doing in Ideology 
and Curriculum bore little resemblance to what was happening in the day-to-day life of these workers on the assembly line. They were dominated in some very interesting ways ideologically-the hegemonic form was visible-but it was also very contradictory and they were struggling with it every day. So again there was this constant dialectical process between the action I was doing in working with the union and having to rethink, massively, the positions I was taking that said, well, people by and large internalize these things and do so in an unmediated way. And again, while many of the workers were often sexist and often very racist, their situation actually looked closer to Paul Willis' work with its emphasis on class capacities and cultural production than it did to the more straightforward reproductive emphasis that I had partly slid into by the end of Ideology and Curriculum. So, yes, the theories were more advanced than practice, but the practice was quickly catching up and pushing the theory another way.

Morrow: Could we move up to the present? I think those of us working in Canada, for example, are quite impressed by the incredible, remarkable development in critical scholarship in the United States over the past 10 to 15 years. But the other side of that, of course, is the grim reality of American politics. The new Bush administration continues the longer term of Republican hegemony, and also the public invisibility (perhaps except for Jesse Jackson) of the kind of concerns expressed in your work in the mass media and in the overt political agenda. What is your assessment of the possibilities for long-term transformation given the deadlock at this particular moment, and the invisibility of what you represent outside of fringe communities and the academy?

Apple: That is a very complicated question. By and large it is the case that the left is more marginal in the United States. The United States has a very populist nature, and populism can be transformed in a right-wing direction or a left-wing direction. Right now, with the fracturing of what I call in recent work "the social democratic accord"-the liberal accord-there is an alliance of the new right, the fraction of the new middle class that gets its own mobility through accountability measures, management techniques, and so on-neoconservative academics, and economic modernizers. This alliance clearly is winning in important ways. I think your analysis of the situation is correct. Part of the tragedy of this at the level of people at universities, in labor unions, and so forth has been their participation in making that happen. 
Morrow: By the attack on liberalism?

Apple: Yes, in part. Let me explain the emerging situation. I think there has been a rapprochement with what is called liberal "person rights" by many people on the left now. Earlier, we tended to see liberalism as simply an attempt by ruling-class interests to mystify certain things. More and more, however, it is quite clear that many of what used to be called "bourgeois rights" were the result of struggles. They were not simply ways of co-opting dissent. Instead, they were compromises, accords. We began to realize that our attacks on liberalism in education and elsewhere - which were correct in many ways - came at a time when it would have been wiser to focus more on the real concerns of people in local communities. We too often forget about how tenuous these "liberal" gains actually are in the long history of the particular kinds of struggles at the present time. Also-and this is where I think many of us created troubling results-I think that much of the discourse that we participated in was truly negative criticism. Negative work is important, of course, as a form of bearing witness to oppression, but often it did not give people a sense of possibility. It also was done at such a theorized level that it was unable to connect to the real-life experience of people-and that is a tragedy. This partly enabled the creation of a situation in which the right has been able to rebuild its hegemonic forms around people's real sense of anger. There are populist sentiments in the United States, for example, that are fundamentally opposed to big business, but somehow the right has been able to recuperate those feelings. The left and populist forces should be able to work with that, but we have been unable to do so because we have been too concerned with our elegant abstractions and have forgotten about the connections we have to make with real life. For too many of us, our only political work is writing for other theorists. I don't want to disparage this; such writing is crucial. But in the process, we have all too often given the political and educational field over to the right and have let them define the public agenda.

Torres: What would probably be the reason for that? My experience in the U.S. has been very brief, but while I was at Stanford, I had the sense that there was a kind of break between the old left and the new left in the U.S. which effected the creation of a socialist tradition. Would that be one of the reasons why the focus of attack was misplaced in this new wave of criticism of schooling?

Apple: I don't think that the focus of criticism was totally misplaced, and I think that I am still largely opposed to the 
liberal tradition as a tradition that is isolated from the roots of oppressive conditions. But I do think that there were major gains within it, and they must be repoliticized. Our task, then, is in part to defend and extend these gains in more democratic directions in all of our institutions, both public and private. This is a program of radical democracy. Parts of this program are already there if they can be reconstructed. For instance, the tradition of socialist work in the United States in education is very long. This is not new. For this reason, I object to being called a reconceptualist. I am not reconceptualizing anything, but building upon and reconstructing a whole history of the relationship between cultural politics and democratic socialism in the United States. There were always alternatives, and many of the same kind of claims I am now making other people were making in 1910 and 1920 . If you want to talk about where the blame lies, the socialist tradition and the populist tradition in the United States have been marginalized consciously and placed under attack for decades. Remember, this is the country of the "Red" scares, the Palmer raids, and so forth. Thus, while there were serious problems with "old left" approaches, rather than blaming major parts of the critical tradition for its lack of connectedness or for some of its partly misplaced criticisms, we might want to remember the history of its forced marginalization.

Morrow: That was at the end of World War I when the socialist parties became scapegoats for fears about the Bolshevik Revolution in Russia, and the socialist parties were destroyed by police professionals.

Apple: Yes, part of the results are seen in the fact that the union movement in the United States is still among the smallest, in terms of the percentage of people, in most western industrialized nations. Unions have won major victories and have helped create the social-democratic accord, but they also have been weakened by the state through oppression, marginalizing, and so forth. So we want to be cautious about blaming the left for fracturing itself, even though the joke about how many Marxists it takes to go fishing is correct. The answer is $100-$ one to hold the pole and 99 to argue about the correct line. We have been culpable about that. But again this is also part of a longer story. The United States has always been less able to build a large-scale socialist tradition in part because the boats were often just as filled with immigrants going back as they were coming. Many people who were often the most politically active did not stay because either they didn't make it or they went back repeatedly to deal with pressing problems. As well, the vast 
openness of the nation and the fact that political liberties for white males were granted originally at the beginning of nationhood meant that, unlike in, say, England, they did not have to be struggled for as much as part of a class-based politics. It was in England where class politics and political struggles had to be joined. In the United States, there was a very different articulation of that struggle. That means that it is very hard still to organize around an avowedly socialist program in the United States. To make a difference it has to be populist. Although class relations do have a long history in the United States, they are given a peculiar flavor due to the specific political, cultural, and religious history of the country.

Morrow: May I ask you a related question? From the point of view of Canadian and European observers, one of the things that is most distinctive about American political culture is the predominance of single-issue politics which reflects the absence of this integrated framework which a socialist movement would provide, and which the liberal program did provide for a period. Do you see this still as an ongoing problem?

Apple: Yes. One of the things the right has been markedly successful in doing is forming coalitions of single-issue groups around a particular agenda. An agenda in education of standardization, of a false "common culture," of a romanticized past, of guaranteeing a connection between school and paid work, this is the coalition that has been formed. The right has been able to do this, to provide this hegemonic umbrella. In essence, it says, we will compromise. You want certain things (for example, populist and middle class forces that want mobility and opportunities). We will give you that provided you form this coalition under the umbrella of economic modernization (to compete with the Japanese, and so forth). The right has blended together themes of nationalism and patriotism, "pro-family" issues, standards, sexuality, drugs, and so on under its own leadership and has used them for its purpose of taking an economic ideology of "free enterprise" and spreading it into every sector of society. Single issues have been in fact articulated together brilliantly by the right in the U.S. But I think the prospects for that coalition being retained structurally are slim. In order for economic modernization to take place in this way, "capital" must be set loose. Now the ideological forms of capital, and the way capitalism itself operates as an economic mode, means that commodification must subvert sacred traditions and visions of sacred knowledge. Thus, as a paid worker, I must not get meaning on my job. I have to wait until I am walking out of the factory, out of my office, going on my vacation or buying 
a TV or a VCR or having a camper. Yet, in the process, discipline on the job is subverted. At the same time, to maintain legitimacy and create profits, our economy must act against the romanticized visions of the family, home, and school, of women's place being defined only by the domestic sphere. Thus the new right populists' ideology cannot combine with the "free market" emphasis on making everything for sale

Morrow: A Disney view of the world?

Apple: In part, yes, which is under threat. You cannot have industrialization and unleash these market forces and at the same time defend traditional positions on the family and sacred knowledge of the past. They are mutually exclusive. So my sense is that this coalition must fracture in the long run. All this means is that it gives us the objective possibility of forming coalitions between those of us who favor democratizing the school and the paid and unpaid work place and these other disaffected groups. We can form a different coalition that articulates these people who are now being organized by the right with more democratic positions.

Torres: Hearing you previously discussing the role of informal education I was very pleased. You are not known as a nonformal educator, but as a school-based researcher. May this assumption that a right-wing coalition cannot hold indefinitely lead you to say, yes, there is a need to develop new forms of resistance in education as the eventual basis of a more "offensive" strategy? Is that a fair reading of your comments?

Apple: Yes, definitely. The hard part is to try to find out where the appropriate group is. However, this makes it sound too strategic, unfortunately, and less organic than what I mean. I have moved to a position that might be called a position of "decentered unity." I no longer believe that class is the fundamental engine that provides the only organizing force for social change. I articulated in Teachers and Texts-my most recent text-a parallelist position where there are multiple agents and multiple struggles. Social movements including and often going well beyond class dynamics are powerful agents here.

Morrow: So you have been influenced by poststructuralist debates but not taken in hook, line, and sinker in the way some might accuse, say, Philip Wexler?

Apple: Definitely. Philip is a dear friend of mine and we have written things together, and as you know his volume on this appeared in the book series Critical Social Thought that I edit. 
I think that his intuitions are probably correct. That is, we have to decenter the notion that class is the only place where human agents are available. That is made visible if we look at the issue of gender politics, with men as well as women. Perhaps not so oddly, this is actually a return to my previous politics where I was not only formed in part by working-class politics because of the political background of my family - a family union tradition, having been a printer myself, and so forth. As I mentioned earlier, I was also profoundly formed personally in racial politics. So it's a return to part of my biography. But some of the poststructuralist position worries me and I will be honest about this. I think that we can multiply forms of domination to such an extent that there are no meaningful organizations left to combat oppression. I think the position is often an embodiment of the postmodern condition itself; that is, it mirrors our inability to see and to recognize what structures exist and how they actually work in relation to domination.

Let me give you an example. I must admit that when I am in Brazil, Thailand, and other countries doing educational and political work and walking into the slums to work with groups of people struggling to keep babies alive, to find enough food to eat, to even get a minimum of schooling for their children, and when I work with others to build international movements to support these peoples' struggles-because of all that, I think the relations that make up what we can objectively call capitalism are much more oppressive than other kinds of relations in many situations. In our (largely meritorious, as feminist theory has brilliantly shown) attempts to move beyond class reductionism and recognize how domination in race, class, gender, sexuality, and other relations works, we have at times forgotten the massive structuring forces that do exist. And because of personal experience, perhaps because I grew up poor, I think that we must begin to think through what are the dangers of a position that rests totally on the notion that there is an infinite multiplicity of discourses of power, that is to say, the notion that everything is an equal form of oppression, isn't it? For political reasons, I don't think we can say that. Of course, we must organize with people in their own felt sense of oppression. That's the phenomenological urge, that's cultural politics. However, I must admit that in my heart of hearts I don't think that all oppressions are equal, that I think there are vicious results arising out of the national and international movement to bring all of us the "benefits" of capitalist economies, cultures, and politics. It is not only an image; these are real objective conditions. Talk about discourse is powerful and freeing indeed; but unless we recognize its limitations and its current overtheoriza- 
tion, we will also be in danger of our own kind of mystification while the world crumbles around us and the lives and hopes of identifiable people are shattered. It is important, though, that I not be misunderstood here. I do not want to dismiss the utter power of race and gender oppressions. The brutality of the oppression of women in what is called the "domestic sphere" is exactly that-brutal. My point, however, is to have us focus on material conditions, something we are forgetting in our rush to see everything in "discursive" terms.

Morrow: Let's change the focus a bit to the world system and particularly the relationship between metropolitan countries and dependent countries.

Torres: It's clear from this conversation that the three of us are outside the mainstream positivist traditions of (North) American society. But I am a double outsider coming from a Third World society. The question I have is How can we discuss the creation of a transformative teacher who is part and parcel of a more comprehensive system of domination and control in a metropolitan society in the context of the World System?

Apple: I think one has to struggle where one is. I don't want to dismiss the issue of understanding the international context in which we exist. All of our actions need to be interpreted relationally. For instance, take the fact that to do this interview we walked into this room and turned on a light. We can interpret this act positivistically as an objective fact. We could simply say that Michael Apple walked into this room in which we were able to videotape and I turned on a light. Yet this interpretation is not social enough. It doesn't recognize that not only did I turn on a light, but in the process I had an anonymous social relationship with the miners that have dug the coal and died in the process so that the electricity was produced to enable the light to go on. So I think we want to think about these things in terms of our concrete relations with other people. This obviously requires that we think in international terms; I agree with that. Yet there is also a theoretical and political issue about changing the minds of people in the center, people who now do not recognize how much their comforts rest on the work of people in poorer nations. To the extent that alterations within the imperialist center have an impact at the level of people's lives outside that political center, I think we have no choice but to engage in political education with teachers, children, adults, and others here to make it clear how their everyday lives are in fact tied up in systems of domination. It is important for us to understand that to make the cultural, political, and economic conditions of Third World peoples less oppressive, changes must 
be made not simply in Mexico, or Nicauragua, or elsewhere, they also must occur in the capitalist center, the belly of the beast, the U.S.A.

Now, I am constantly reminded of this because many of my students come from nations that have oppressive governments or that are newly democratized. I too spend a good deal of time in those nations myself, and in fact was arrested and ultimately sent home from one repressive nation in Asia because I spoke out against the government's antidemocratic policies in education and politics. This means that we as educators must take a stand against antidemocratic relationships wherever they are found. For whatever power education has, it can make clear to teachers what the relationships are. I am not saying that this will alter the universe of multiple oppressions on an international scale, but I think, to the extent that I call myself someone . who is an educator, I have no choice but to act.

Yet "center/periphery" relations do not exhaust these issues. There is a third world within the first world. I am not only talking about what goes on in Argentina or Chile or Brazil. I must talk about third world peoples in the United States and that's part of the struggle that many people have to understand as well. We're not simply exporting the working class of the United States or Canada to Malaysia or Haiti or elsewhere. We are exploiting third world populations in the United States. We're destroying them at the same time through economic and educational policies and practices that are truly disabling. There are nations inside this nation, and again the educational practice that goes on surrounding that issue is critically important. That is the Gramscian part of me. You surround the imperial center not just outside the nation but inside it as well with alternate cultural and political forms. Thus our task is also to surround the relations of cultural and economic exploitation at home and also build possibilities here. This, of course, involves concrete work at the level of pedagogy and curriculum to recapture our lost collective memories of successful struggles, and to continue the path that Raymond Williams so cogently called the long revolution.

Morrow: I would like to suggest one final question without wanting to promote divisiveness within the tradition of radical and critical educational scholarship. How would you respond to the kind of strategy represented by Henry Giroux, in particular his emphasis on the language of possibility, and so forth, and his attempt to draw on critical theory in the Frankfurt tradition, as well as his relation to Paulo Freire? How would you view that in relationship to the kinds of strategies that you represent? 
Apple: Henry and I have been good friends for a number of years. I was the first to reestablish the Neo-Marxist cultural tradition in the early ' 70 s in the United States, before Henry and others joined me. Being largely alone in 1970, it was a pleasure to welcome him on stage in the middle of the decade. When Henry first began writing, he in essence apprenticed himself to me. In the process we both taught each other a good deal. He is clearly very smart and has an exceptional ability to integrate work together. We all stand on people's shoulders. For a number of years, Henry stood on mine, and there were times when I stood on his. There have been times when we have criticized or will criticize each other both in print and elsewhere. Yet I think this has to be done in an immensely comradely (or sisterly) manner. There are times that we disagree. For example, there may be a danger with the level of overabstraction of his work at times. There are times when we must make clear connections with people's lives and sometimes that requires a level of specificity that Henry sometimes doesn't have. While I am less sanguine about the poststructuralist tradition than he is, I am now even less enamored of the critical theory tradition than he is, in part perhaps because my training was initially Habermasian. I had left that for particular conceptual and political reasons, in part because $I$ think that there are traditions (for example, the neo-Gramscian and the radical democratic) that say it better and clearer and offer a different and more democratic kind of politics as well. On the other hand, I think the work he is doing with Aronowitz on the Bloom-Hirsch debate in the United States is of critical importance to cultural politics. So again, by and large I will do nothing but support his work, though perhaps he, like many of us, could value criticism of our work more. I was chosen by the faculty there to be an outside evaluator in his tenure case at Boston University where he was brutally and unethically dealt with. I supported him as much as I could then.

I think our task is to criticize each other in the best sense of learning from each other; otherwise how will the tradition grow and learn from its mistakes? Because we are on the left we must model a kind of openness and democratic behavior in our own discourse. We must welcome criticism-when it is itself given in an open and honest fashion-if we are not to recapitulate the relations we are supposed to be fighting against.

Torres: You have drawn a lot of material from Freire. What would be your main criticism of the Freirean approach? What would be the idea of Freire that impressed you most? 
Apple: There are few people I am willing to sit at the feet of-and Freire is one of them. He is someone $\mathrm{I}$ am proud to say I know. But with all people there are times, there are certain things we must criticize. We have a tendency to create gods. I know this is uncomfortable for Freire. When I was in Brazil, it became quite clear to me that there were many people who are progressive who also disagree with him, and one of the disservices I think we do in creating gods is that we forget that there are debates over their work in their own nation. So the first thing I would suggest that we do is to find out what the debates are over Freire's pedagogical theories where they were developed. In this way, we can make certain we do not import things that could be strengthened by linking to those original multiple and often conflicting traditions. We could then better understand their strengths and weaknesses as opposed to seeing them just as political/pedagogical resources that can be used anywhere, with no necessary reconstructions and no thought given to their contradictions.

While I very much agree with the notion that one begins one's pedagogy in the lived experience of actors and that there are ways of stimulating that-and here Friere is unparalleled in the world-I am in other ways probably more Gramscian in that I think that we have given up too much on the question of content. I am distressed in part by an idea that says that when dealing with people in creating political literacy, which is a slow process, we assume that the knowledge that we too often call "bourgeois" is not essential for engaging that literacy. We assume that the necessary resources are always somehow already there in the community and we do not need to bring them. I think that all of this knowledge, even in the traditional disciplines, was built from the labor of these people. It is theirs and it deserves to be theirs. I would go further-though I think that the pedagogy might be the same-and would take much more seriously the issue of content. I also think that we are in danger of appropriating, and making politically safer, material that was developed in the Third World and in practical kinds of struggle. In this way, we contribute to the loss of its critical commitment to liberation. As I said, I don't think it is easy to translate that into our classrooms and I don't think the conditions are necessarily exactly the same. So I think it has to reappropriated, rebuilt around the themes, the structures, of the lives of real people in industrialized nations. We need to be very careful not to simply create another bandwagon. I think that what we too often do is to take on Freire as an easy model, as simply a transportable technique, a technique to pull out of our pocket, forgetting that it is built in struggle and it must be 
reconnected and rebuilt with the people. Thus there are a variety of dangers that I see. On the other hand, Freire's approach is such an advance over the normal ways of how we think about nonformal education, about whose knowledge is appropriate, and how we can articulate that in a very critical way, that it would be an act of bad faith not to allow it to influence much of what we do.

Our work is a form of cultural politics. This involves all of us working for what Williams called the "journey of hope" toward "the long revolution." To do less, not to engage in such work, is to ignore the lives of millions of students and teachers throughout the world. Not to act is to let the powerful win. Can we afford to let this happen?

\section{Note}

1. This interview took place at the University of Wisconsin in Madison on April 28, 1989. Michael Apple is a professor in the Departments of Curriculum and Instruction and Educational Policy Studies at the University of Wisconsin. 